\title{
Effects of Fescue Type and Sampling Date on the Ruminal Disappearance Kinetics of Autumn-Stockpiled Tall Fescue ${ }^{1,2}$
}

\author{
R. Flores, ${ }^{\star}$ W. K. Coblentz, $\dagger^{3}$ R. K. Ogden, ${ }^{\star}$ K. P. Coffey, ${ }^{\star}$ M. L. Looper,‡ C. P. West, $\S$ \\ and C. F. Rosenkrans Jr.* \\ ${ }^{*}$ Department of Animal Science, University of Arkansas, Fayetteville, 72701 \\ †USDA-ARS, US Dairy Forage Research Center, Marshfield, WI 54449 \\ ¥USDA-ARS, Dale Bumpers Small Farms Research Center, Booneville, AR 72927 \\ §Department of Crop, Soil, and Environmental Sciences, University of Arkansas, Fayetteville, 72701
}

\section{ABSTRACT}

Two tall fescue (Festuca arundinacea Schreb.) forages, one an experimental host plant/endophyte association containing a novel endophyte (HM4) that produces low or nil concentrations of ergot alkaloids, and the other a typical association of Kentucky 31 tall fescue and the wild-type endophyte (Neotyphodium coenophialum; E+), were autumn-stockpiled following late-summer clipping and fertilization with $56 \mathrm{~kg} / \mathrm{ha}$ of $\mathrm{N}$ to assess the nutritive value and ruminal disappearance kinetics of autumn-stockpiled tall fescue forages. Beginning on December 4, 2003, sixteen $361 \pm 56.4$-kg replacement dairy heifers were stratified by weight and breeding and assigned to one of four 1.6-ha pastures (2 each of E+ and HM4) that were strip-grazed throughout the winter. Pastures were sampled before grazing was initiated (December 4), each time heifers were allowed access to a fresh strip (December 26, January 15, and February 4), and when the study was terminated (February 26). For fiber components, there were no interactions between fescue type and sampling date for either pregrazed or postgrazed forages. Over sampling dates, neutral detergent fiber (NDF; 56.5 to $67.8 \%$ ), acid detergent fiber (27.7 to $34.9 \%$ ), hemicellulose (28.8 to $34.0 \%$ ), cellulose (25.0 to $28.1 \%$ ), and lignin (3.61 to $10.05 \%$ ) varied with sampling date, but patterns were almost exclusively curvilinear with time. Ruminal disappearance rate of dry matter (DM) was not affected by any treatment factor (overall mean for both pregrazed and postgrazed forages $=0.050 \mathrm{~h}^{-1}$ ); similar responses were

Received November 3, 2006.

Accepted January 28, 2007.

${ }^{1}$ This project was funded in part by USDA Cooperative Agreement \#58-6227-8-040.

${ }^{2}$ Mention of trade names or commercial products in this article is solely for the purpose of providing specific information and does not imply recommendation or endorsement by the U.S. Department of Agriculture.

${ }^{3}$ Corresponding author: coblentz@wisc.edu observed for NDF disappearance (overall mean $=0.048$ $\mathrm{h}^{-1}$ ). Interactions of fescue type and sampling date were observed for both pregrazed and postgrazed forages with respect to effective ruminal disappearance of $\mathrm{DM}$; however, estimates were relatively high for all forages (overall mean $=64.0 \%$ ). Effective disappearance of NDF was relatively extensive for all forages (overall mean = $55.4 \%$ of NDF). Based on the results of this trial, the endophyte status of stockpiled tall fescue forages had little practical effect on forage nutritive value and kinetics of ruminal DM or NDF disappearance. Overall, autumn-stockpiled tall fescue forages would appear to be a legitimate and lower cost alternative to harvested forages, and appear to possess suitable nutritional characteristics for developing dairy heifers in the Ozark Highlands.

Key words: tall fescue, replacement heifer, disappearance kinetics, grazing

\section{INTRODUCTION}

Beef and dairy cattle grazing tall fescue forages infected with the wild-type fungal endophyte Neotyphodium coenophialum (Morgan-Jones and Gams) Glenn, Bacon, and Hanlin comb. nov. (Glenn et al., 1996) often develop a condition known widely as fescue toxicosis. Ergot alkaloids produced by this fungus are responsible for the various symptoms of toxicosis observed commonly in cattle consuming these forages. Specifically, cows, calves, growing heifers, and stocker cattle exhibit reduced DMI (Forcherio et al., 1995; Humphry et al., 2002), poorer fiber digestion (Hannah et al., 1990; Humphry et al., 2002), elevated rectal temperatures (Goetsch et al., 1987; McMurphy et al., 1990; Parish et al., 2003), depressed concentrations of serum prolactin (Parish et al., 2003; Nihsen et al., 2004; Watson et al., 2004), rough hair coat (Fribourg et al., 1991; Peters et al., 1992; Nihsen et al., 2004), increased respiration rates (Peters et al., 1992; Nihsen et al., 2004), depressed weight gains (Nihsen et al., 2004; Watson et al., 2004; 
Coblentz et al., 2006), and reduced milk production (Holloway and Butts, 1984; Peters et al., 1992; Coblentz et al., 2006). A somewhat dated estimate suggests that these problems cost livestock (mostly beef) producers in the United States about $\$ 609$ million annually (Hoveland, 1993).

Although the association of Neotyphodium coenophialum with its tall fescue host clearly affects livestock performance negatively, the same endophyte is known to enhance host-plant competitiveness and persistence relative to endophyte-free plants with the same genetic background (Bouton et al., 1993; West et al., 1993; Malinowski and Belesky, 2000). Recently, unique associations of improved tall fescue varieties with novel endophytes that produce little or no measurable ergot alkaloids have been developed (Bouton et al., 2002; Nihsen et al., 2004) that appear to alleviate most of the classical symptoms of fescue toxicosis in livestock (Parish et al., 2003; Nihsen et al., 2004; Watson et al., 2004). This outstanding advancement in forage and livestock science is further coupled with cautious optimism that these novel associations of nonergot-alkaloid-producing endophytes with host plants may retain many of the symbiotic relationships that support superior persistence and stand survival relative to host plants not infected with an endophyte. This is especially relevant throughout the Ozark Highlands, where growing conditions for perennial cool-season grasses are quite stressful. Many Ozark pasture soils are shallow, have poor water-holding capacity, and are often acidic with relatively low fertility (Sauer et al., 1998).

Although much of the existing tall fescue and (or) livestock research has evaluated plant and animal performance during the spring and summer months, there has been increased interest in autumn stockpiling of tall fescue forage for grazing livestock during winter (Kallenbach et al., 2003; Teutsch et al., 2005). Tall fescue is preferred for autumn stockpiling over other perennial cool-season grasses for a variety of reasons, a summary of which was compiled by Kallenbach et al. (2003): 1) the percentage of total annual forage production occurring in the fall is greater than observed for many other perennial cool-season grasses; 2) initial evaluations suggest there is excellent stability of nutritive value throughout the winter; and 3) defoliation by livestock during winter has a minimal effect on forage growth throughout the following spring. In addition, elongation and seedhead development for tall fescue occurs only in the spring; therefore, autumn-stockpiled forage is entirely leaf, which likely contributes to the desirable characteristics of nutritive value observed routinely throughout the late autumn and winter (Kallenbach et al., 2003). Currently, there is little research information available that describes the kinetics of ru- minal DM and NDF disappearance for autumn-stockpiled tall fescue forages, or that describes how kinetic parameters may be affected by specific associations of host plant and endophyte, or grazing by livestock. Our objectives were to evaluate the nutritive value and in situ disappearance kinetics of DM and NDF for pregrazed or postgrazed autumn-stockpiled tall fescue forages harvested on 5 dates throughout the winter in the Ozark Highlands.

\section{MATERIALS AND METHODS}

\section{Pasture Maintenance}

Four 1.6-ha pastures located in Fayetteville, Arkansas, contained either an experimental host plant/endophyte association with a novel endophyte that produces low or nil concentrations of ergot alkaloids (HM4; Nihsen et al., 2004), or a typical association of Kentucky 31 tall fescue with the wild-type endophyte (Neotyphodium coenophialum; E+). Each tall fescue type was established within 2 of the 4 experimental pastures. Soil types located within the experimental area were primarily a Pickwick silt loam (fine-silty, mixed, active, thermic Typic Hapludults), and a Captina silt loam (fine-silty, siliceous, active, mesic Typic Fragiudults), both with 1 to $3 \%$ slopes. Before initiating the study, these pastures had been used for a variety of summer and winter grazing trials since establishment in October 1998. During the summer of 2003, pastures were grazed intermittently to remove existing vegetation, and then clipped to a common 7.5- $\mathrm{cm}$ stubble height with a rotary mower on September 9, 2003, to remove residual forage that remained after summer grazing events. On September 10, all pastures were fertilized at a rate of $56 \mathrm{~kg}$ of N/ha with ammonium nitrate (34$0-0)$. Prior to September 10, pastures had been fertilized with $56 \mathrm{~kg}$ of N/ha on April 22, 2003, and with any needed $\mathrm{P}, \mathrm{K}$, or lime required to meet soil-test recommendations (Chapman, 2001) on July 16, 2003. All animals were removed from pastures before clipping on September 9, and were withheld from the pastures until the initiation of grazing and forage sampling on December 4, 2003.

\section{Grazing Management}

On December 4, 2003, sixteen $361 \pm 56.4$-kg dairy heifers were stratified by weight and breed type (Holstein or Jersey $\times$ Holstein), and assigned to 1 of the 4 experimental pastures ( 4 heifers per pasture). Replacement heifers were utilized solely for grazing pressure, and to create grazed forages that could be sampled, and then evaluated for nutritive value and ruminal disappearance kinetics. Initially, heifers in each pas- 
ture were allowed to strip graze a 0.4-ha area, or approximately $25 \%$ of each pasture. A single-lead electric wire was used to restrict heifers from grazing the entire 1.6-ha pasture. Heifers were allowed to graze the initial strip for about $21 \mathrm{~d}$. During this time, heifers had ad libitum access to fresh water, and were offered a cornbased concentrate supplement on a group basis at 1700 $\mathrm{h}$ each day at a rate equal to $2.0 \mathrm{~kg} / \mathrm{d}$ for each individual heifer. The supplement contained (as-is basis) $60.0 \%$ cracked corn, $33.6 \%$ cottonseed hulls, $2.0 \%$ fish meal, $1.0 \%$ liquid molasses, $0.8 \%$ salt, $0.2 \%$ dicalcium phosphate, $1.0 \%$ limestone, $0.3 \%$ potassium chloride, $0.2 \%$ magnesium oxide, with the balance $(0.9 \%)$ in a blended trace mineral and vitamin formulation.

On December 26, January 15, and February 4, heifers in each pasture were allowed access to an additional 0.4 ha $(25 \%)$ of each 1.6-ha pasture by advancing the lead electric wire. No back wire was used; therefore, heifers had continued access to all postgrazed strips after the lead electric wire was advanced. This technique is consistent with procedures used commonly by producers throughout the region. Grazing was terminated on February 26, after heifers had spent a total of $84 \mathrm{~d}$ on pasture.

\section{Pasture Sampling}

Pregrazed Forages. Pastures were sampled when cattle were assigned initially (December 4), on each day that heifers were allowed access to a new strip (December 26, January 15, and February 4), and when grazing was terminated (February 26). For the initial sampling date, pregrazed forage mass was estimated by clipping all the forage within four $0.25-\mathrm{m}^{2}$ frames to a $2.5-\mathrm{cm}$ stubble height with garden shears. Frames were placed randomly throughout the first 0.4-ha strip that heifers entered when the trial was initiated on December 4. For the December 26, January 15, and February 4 sampling dates, pregrazed forages were sampled in an identical manner from the fresh strips that heifers were entering for the first time on those dates. On the date that grazing was terminated (February 26), an estimate of pregrazed forage mass was obtained by again clipping $0.25-\mathrm{m}^{2}$ frames from within 4 circular (1.6-m diameter) exclosures that were positioned at random before grazing was initiated. Additional samples of pregrazed forage were collected adjacent to each frame placement to determine concentrations of ergovaline within experimental forages. After collection, these tall fescue samples were sealed immediately in plastic freezer bags, submerged in ice in an insulated cooler, and then transported to an ultra-low temperature freezer $\left(-80^{\circ} \mathrm{C}\right)$, where they were stored pending analysis for ergovaline. Samples were composited by treatment before analysis for ergovaline.

Postgrazed Forages. Postgrazed forages were sampled similarly from 4 random locations within the strip that heifers were exiting on December 26, January 15, February 4, and when grazing was terminated. To ensure that there was adequate postgrazed forage for the subsequent planned analyses, and to provide a better estimate of residual forage mass, a paired set of $0.25-\mathrm{m}^{2}$ frames (located within $2 \mathrm{~m}$ of each other) were clipped at each of 4 random locations within each grazed strip on each sampling date.

\section{Laboratory Analysis of Forages}

All clipped forages were dried to constant weight under forced air at $50^{\circ} \mathrm{C}$, and then ground through a Wiley mill (Arthur H. Thomas, Philadelphia, PA) fitted with either a 1- or 2-mm screen. Portions of each sample ground through a $2-\mathrm{mm}$ screen were stored in sealed plastic bags at $24^{\circ} \mathrm{C}$, and retained for subsequent ruminal incubation in situ. Forage samples ground through a 1-mm screen were analyzed for whole-plant ash, $\mathrm{N}$, $\mathrm{NDF}, \mathrm{ADF}$, hemicellulose, cellulose, and acid-detergent lignin. Whole-plant ash was determined as the percentage of total plant DM remaining after combustion at $500^{\circ} \mathrm{C}$ for $8 \mathrm{~h}$ in a muffle furnace. Analysis of NDF and other fiber components were conducted sequentially, using batch procedures outlined by Ankom Technology Corp. (Fairport, NY) for an Ankom 200 Fiber Analyzer. Neither sodium sulfite nor $\alpha$-amylase was included in the NDF solution. Concentrations of $\mathrm{N}$ were quantified by a rapid combustion procedure (AOAC, 1998; method 990.03; Elementar Americas Inc., Mt. Laurel, NJ), and $\mathrm{CP}$ was calculated by multiplying the percentage of $\mathrm{N}$ in each sample by 6.25 . Frozen $\left(-80^{\circ} \mathrm{C}\right)$ samples of pregrazed forages collected for determination of ergovaline were lyophilized, and then ground through a Wiley mill equipped with a 1-mm screen. These samples were then returned to the ultra-low temperature freezer until they were analyzed for ergovaline using HPLC (Moubarak et al., 1996).

\section{In Situ Incubation of Experimental Forages}

Animal Care. Five $565 \pm 35.1$-kg ruminally cannulated crossbred (Gelbvieh $\times$ Angus $\times$ Brangus) steers were used for the ruminal incubations of tall fescue forages. Cannulations and care of the steers were approved by the University of Arkansas Animal Care and Use Committee (Protocol \#05005). Steers were housed in individual $3.4-\times 4.9-\mathrm{m}$ pens with concrete floors that were cleaned regularly, and were offered a basal diet consisting of alfalfa hay $(20.7 \% \mathrm{CP}, 49.2 \% \mathrm{NDF}$, and 
$37.7 \% \mathrm{ADF}$ ) and cracked corn. On an as-fed basis, the basal diet contained $85.0 \%$ alfalfa hay and $14.8 \%$ cracked corn. Trace mineralized salt comprised the balance $(0.2 \%)$ of the total basal diet, and was top-dressed over the cracked corn at each feeding. The diet was offered, without refusal, in equal portions at 0700 and $1700 \mathrm{~h}$ for a daily rate of DMI at $2.25 \%$ of BW. Fresh water was available continuously on an ad libitum basis, and steers were adapted to the basal diet for $10 \mathrm{~d}$ before initiating the trial.

Kinetic Procedures. To reduce the number of forages to a manageable number for this type of analysis, forages with common treatment effects (fescue type, sampling date, grazing status) were composited over pasture replicates before conducting kinetic evaluations. Therefore, 18 treatment combinations were evaluated simultaneously in the cannulated steers; these included pregrazed forages of 2 fescue types (HM4 and $\mathrm{E}+$ ), each of which were harvested on 5 sampling dates for a subtotal of 10 pregrazed forages. Postgrazed forages also included 2 fescue types, but were sampled on only 4 dates for a subtotal of 8 postgrazed forages.

In situ procedures were consistent with the standardized techniques described by Vanzant et al. (1998). Fivegram samples of each dried forage were ground through a 2-mm screen, and then weighed into Dacron bags (10 $\mathrm{cm} \times 20 \mathrm{~cm} ; 50- \pm 10-\mu \mathrm{m}$ pore size; Ankom Technology Corp.) that were heat sealed with an impulse sealer (Type TISH-200; TEWI International Co., Ltd., Taipei, Taiwan). Before insertion into the rumen, all Dacron bags were placed in $35-\times 50-\mathrm{cm}$ mesh bags and incubated in tepid water $\left(39^{\circ} \mathrm{C}\right)$ for $20 \mathrm{~min}$. Samples were then suspended in the ventral rumen immediately before the $0700 \mathrm{~h}$ feeding and incubated for $3,6,9,12$, $24,36,48,72$, or $96 \mathrm{~h}$. Upon removal from the rumen, bags were rinsed immediately in a top-loading washing machine (model LXR7144EQ1; Whirlpool Corp., Benton Harbor, MI). Rinsing procedures included 10 coldwater rinse cycles ( $47 \mathrm{~L}$ of water), where each cycle consisted of $1 \mathrm{~min}$ of agitation and $2 \mathrm{~min}$ of spin (Coblentz et al., 1997; Vanzant et al., 1998). A separate set of bags was preincubated and rinsed without ruminal incubation $(0 \mathrm{~h})$. After rinsing, the sample residues were dried to a constant weight at $50^{\circ} \mathrm{C}$, and equilibrated with the atmosphere before determination of residual DM (Vanzant et al., 1996). For each forage at each incubation time, the percentage of initial NDF remaining after ruminal incubation was calculated following digestion of a representative subsample in neutral detergent using the procedures described previously (Ankom Technology Corp.)

The percentage of DM or NDF remaining at each incubation time was fitted to the nonlinear regression model of Mertens and Loften (1980) using PROC NLIN of SAS (SAS Institute, 1990). Forage DM was partitioned into 3 fractions based on relative susceptibility to ruminal disappearance. The A fraction was defined as the immediately soluble portion, although it also may include minute insoluble particles that may wash out of Dacron bags (Coblentz et al., 1998; GaldámezCabrera et al., 2003). Fraction B represented the portion of DM or NDF that disappeared at a measurable rate; and fraction $\mathrm{C}$ was defined as the portion of $\mathrm{DM}$ or NDF that was undegraded in the rumen. Fractions $\mathrm{B}$ and $\mathrm{C}$, disappearance rate (Kd), and the discrete lag time were determined directly by the nonlinear regression model. Calculations of Kd were based solely on the rate at which fraction B disappeared from the Dacron bags. For each forage, fraction A was calculated as $100 \%$ $-(B+C)$, and the effective ruminal disappearance of $\mathrm{DM}$ was calculated as $\mathrm{A}+\mathrm{B} \times[\mathrm{Kd} /(\mathrm{Kd}+\mathrm{Kp})]$ (Ørskov and McDonald, 1979), where $\mathrm{Kp}=$ passage rate. Calculations of effective ruminal disappearance for each individual steer were based on the Kp determined experimentally in that same steer during the trial.

Passage Rate of Basal Diet. Ruminal passage rate (mean $=0.026 \pm 0.0036 \mathrm{~h}^{-1}$ ) of the basal diet was determined for each steer using acid-detergent insoluble ash as an internal passage marker. On the final day of the in situ trial, ruminal contents were evacuated manually before feeding $(0 \mathrm{~h})$ and $4 \mathrm{~h}$ after feeding. Total ruminal contents were weighed, mixed, and triplicate samples were dried under forced air at $50^{\circ} \mathrm{C}$ to a constant weight. Samples were stirred periodically to prevent molding. Grab samples of dietary components from the basal diet were collected daily, composited, and dried to a constant weight at $50^{\circ} \mathrm{C}$. Dried ruminal contents and diet samples were ground through a $1-\mathrm{mm}$ screen via a Wiley mill, and concentrations of acid detergent insoluble ash were determined following digestion in acid detergent (Ankom Technology Corp.). Residual ash was determined for these ADF residues following combustion in a muffle furnace at $500^{\circ} \mathrm{C}$ for $8 \mathrm{~h}$. Hourly intake of aciddetergent insoluble ash for each steer was obtained by totaling the daily intake of acid-detergent insoluble ash and dividing it by $24 \mathrm{~h}$. Ruminal passage rate was calculated by dividing the mean acid-detergent insoluble ash intake $(\mathrm{g} / \mathrm{h})$ by the mean ruminal mass $(\mathrm{g})$ of this fraction (Waldo et al., 1972).

\section{Statistical Analysis}

Forage Mass and Nutritive Value. Pregrazed and postgrazed stockpiled tall fescue forages were analyzed independently as split-plot designs because the number of sampling dates differed with grazing status. In each case, tall fescue type (E+ or HM4) was the whole-plot term, whereas sampling date served as the subplot 
Table 1. Monthly mean for daily high temperature and cumulative precipitation at Fayetteville, Arkansas, from September 2003 to February 2004

\begin{tabular}{|c|c|c|c|c|}
\hline Month & $\begin{array}{l}\text { Precipitation, } \\
\mathrm{mm}\end{array}$ & $\begin{array}{c}30-\mathrm{yr} \\
\text { norm, } \\
\text { mm }\end{array}$ & $\begin{array}{c}\text { Mean daily } \\
\text { high } \\
\text { temperature, } \\
{ }^{\circ} \mathrm{C}\end{array}$ & $\begin{array}{c}30-y r \\
\text { norm, } \\
{ }^{\circ} \mathrm{C}\end{array}$ \\
\hline September 2003 & 70 & 123 & 25.9 & 27.1 \\
\hline October 2003 & 89 & 95 & 22.6 & 21.3 \\
\hline November 2003 & 96 & 120 & 15.7 & 13.9 \\
\hline December 2003 & 48 & 81 & 9.9 & 8.7 \\
\hline January 2004 & 36 & 54 & 6.6 & 6.8 \\
\hline February 2004 & 21 & 61 & 7.5 & 10.3 \\
\hline
\end{tabular}

${ }^{1} \mathrm{NOAA}(2002)$.

treatment effect. Whole-plot effects were analyzed as a completely randomized design with 2 replications (pastures) of each fescue type, and tested for significance with the pasture nested within fescue type error mean square by PROC GLM of SAS (SAS Institute, 1990). Sampling dates and the interaction of fescue type and sampling date were tested for significance with the residual error mean square. Single-degree-of-freedom orthogonal contrasts were used to evaluate forage mass and indices of nutritive value for linear, quadratic, cubic, or quartic effects of time.

In Situ Disappearance of DM and NDF. Parameters associated with ruminal in situ disappearance of DM or NDF were analyzed as a randomized complete block design with 5 steers representing experimental blocks. For pregrazed forages, treatment factors were evaluated as a $2 \times 5$ factorial arrangement of fescue types and sampling date. A similar, but independent, ANOVA was conducted for postgrazed forages that included both fescue types, and only 4 sampling dates. Single-degree-of-freedom orthogonal contrasts were used to evaluate kinetic indices for linear, quadratic, cubic, or quartic effects of time.

Comparisons of Pregrazed and Postgrazed Forages. For the December 26, January 15, February 4, and February 26 sampling dates, characteristics of nutritive value and in situ disappearance characteristics for pregrazed forages were compared with those of postgrazed forages by creating a new variable based on the difference between estimates (for example, $\mathrm{NDF}_{\text {pregrazed }}$ - $\mathrm{NDF}_{\text {postgrazed }}$. This difference was subsequently compared with zero using a Student's $t$-test (PROC GLM; SAS Institute, 1990). In all cases, significance was declared at $P<0.05$, unless otherwise noted.

\section{RESULTS AND DISCUSSION}

\section{Forage Mass}

Throughout the trial, precipitation remained below normal for each month from September 2003 through
Table 2. Forage mass for pregrazed and postgrazed autumn-stockpiled tall fescue forages grazed by developing dairy heifers and evaluated on 5 dates between December 4, 2003, and February 26, $2004^{1}$

\begin{tabular}{lccc}
\hline & \multicolumn{2}{c}{ Pregrazed } & \\
\cline { 2 - 3 } Sampling date & HM4 & E+ & Postgrazed \\
\cline { 2 - 3 } & & (kg/ha) & \\
December 4 & 3,650 & 5,170 & - \\
December 26 & 5,040 & 4,836 & 3,684 \\
January 15 & 4,084 & 4,328 & 3,394 \\
February 4 & 3,724 & 3,682 & 2,987 \\
February 26 & 3,976 & 3,768 & 3,219 \\
SEM & 421.0 & 642.5 & 201.0 \\
Contrasts & & $P>F$ & \\
Linear & 0.639 & 0.109 & 0.092 \\
Quadratic & 0.335 & 0.782 & 0.242 \\
Cubic & 0.077 & 0.674 & 0.433 \\
Quartic & 0.444 & 0.883 & - \\
\hline
\end{tabular}

${ }^{1}$ Fescue types (HM4 and $\mathrm{E}+$ ) did not differ $(P \geq 0.470)$ for either pregrazed or postgrazed forages. There was an interaction of fescue type and sampling date $(P=0.016)$ for pregrazed forage; however, no interaction $(P=0.348)$ was observed for postgrazed forages.

${ }^{2}$ Linear, quadratic, cubic, and quartic effects of sampling date.

February 2004; however, the greatest deficits (53 and $40 \mathrm{~mm}$ ) occurred during September and February, respectively (Table 1). Mean daily high temperatures were slightly above normal from October through December 2003, but were below normal for all other months. Forage mass did not differ across fescue types for either pregrazed $(P=0.751)$ or postgrazed $(P=0.470)$ forages. Pregrazed forages exhibited a fescue type $x$ sampling date interaction $(P=0.016)$ that was created primarily by a numerically greater mass for $\mathrm{E}+$ compared with HM4 on the initial sampling date $(5,170$ vs. $3,650 \mathrm{~kg} / \mathrm{ha}$; Table 2); this difference was likely an aberrant response, created by an exceptionally large forage mass in one $\mathrm{E}+$ replicate $(6,104 \mathrm{~kg} / \mathrm{ha})$, rather than any inherent substantive difference in productivity between the 2 fescue types. Although this type of aberrant response could be explained on the basis of inherent variability within and across pasture replicates that is common throughout the Ozarks, it also could be related to past histories within these pastures, where increased cattle traffic around gates, feedbunks, and waterers may have caused changes in productivity within these specific paddocks over time. For all subsequent sampling dates, the maximum difference between fescue types was only $244 \mathrm{~kg} / \mathrm{ha}$. Neither fescue type exhibited a strong relationship with time; HM4 tended to change in a cubic $(P=0.077)$ pattern over sampling dates, whereas $\mathrm{E}+$ tended to decline linearly $(P=0.109)$ over the same time interval.

Postgrazed forage mass was not affected by the fescue type $\times$ sampling date interaction $(P=0.348)$, and only tended to decline linearly $(P=0.092)$ over sampling dates. The overall mean forage mass for postgrazed 
forages $(3,321 \mathrm{~kg} / \mathrm{ha})$ was only $905 \mathrm{~kg} / \mathrm{ha}$ less than observed for pregrazed forages. This relatively small difference, which corresponded to approximately $4.3 \mathrm{~kg} / \mathrm{d}$ for each grazing heifer, or only about $1.2 \%$ of the initial heifer BW daily, may be explained partially on the basis of experimental procedures. Throughout the study, postgrazed forages were sampled only in the 0.4-ha strip that the heifers were exiting on a specific sampling date. Normally, producers throughout the region do not use a back wire when utilizing strip-grazing techniques, thereby allowing grazing animals to access to all strips grazed previously. The grazing management techniques used in this study were consistent with these production norms; therefore, grazing heifers had access to $0.8,1.2$, and 1.6 ha during the $21 \mathrm{~d}$ immediately preceding the final 3 sampling dates (January 15, February 4 , and February 26, respectively). For this reason, it is likely that some repeat grazing of stale strips occurred throughout the trial that was not quantified by these procedures. Another factor potentially affecting forage removal is the presence of fungal endophytes within both forage types that produced measurable concentrations of ergovaline throughout the sampling period. Poore et al. (2000) concluded that performance of cattle grazing autumn-stockpiled tall fescue is not as great as expected based on nutrient concentrations, and that this response is likely related to the use of endophyte-infected fescue in most studies.

Based on our experiences, pastures located in the southern Ozark Highlands are highly inconsistent and notoriously variable, both within and across experimental replicates. Although it was important to quantify forage mass at the time of sampling, this should be viewed as an obligatory side measurement. The primary objective of these procedures was to use a structured, consistent technique to obtain samples for subsequent evaluation of kinetics of ruminal disappearance. Any conclusive evaluation of the growth physiology, yield potential, or estimated intake for these forages that is based on forage mass measurements should ideally include additional pasture replicates, as well as additional estimates of forage mass within replicates.

\section{Ergovaline}

Concentrations of ergovaline in E+ declined over sampling dates $(284,316,109,102$, and $47 \mu \mathrm{g} / \mathrm{kg}$ on December 4, December 26, January 15, February 6 , and February 27 , respectively). This pattern and ranges of concentrations are generally consistent with previous work; Burns et al. (2006) reported a linear decline from October through February for ergovaline within Jessup tall fescue infected with the wild-type endophyte. A similar winter decline of about $85 \%$ was reported by Kallenbach et al. (2003) for stockpiled E+ tall fescue grown in southwestern Missouri. For HM4, measurable ergovaline was observed on each sampling date $(68,77,65,50$, and $48 \mu \mathrm{g} / \mathrm{kg}$, respectively). Comparable concentrations of ergovaline have been reported by Burns et al. (2006) for another tall fescue selection infected with a novel (non-ergot-alkaloid-producing) endophyte (MaxQ; Pennington Seed Inc., Madison, GA) that was autumnstockpiled and sampled from October through February (overall mean $=57 \mu \mathrm{g} / \mathrm{kg}$ ) in North Carolina.

\section{Nutritive Value of Forages}

Pregrazed Forages. For CP and all fiber components, the main effect of fescue type $(P \geq 0.291)$ and the interaction of fescue type $\times$ sampling date $(P \geq 0.064)$ did not affect nutritive value. Whole-plant ash was not affected by any treatment factor $(P \geq 0.241)$. For these reasons, only main effect means of sampling date $(P \leq$ 0.008) are presented (Table 3). The absence of effects created by fescue type is particularly noteworthy, suggesting that endophyte status has little or no effect on nutritive value. This finding is consistent with other work; Fritz and Collins (1991) reported that fiber composition, concentrations of $\mathrm{N}$, and the rate and extent of NDF digestion for spring and summer growth of 2 fescue cultivars (Kenhy and Kentucky 31) were not affected by the endophyte status of the plants. Similarly, Kallenbach et al. (2003) observed little difference between fescue types infected with 1) a toxic, wild-type endophyte; 2) a novel, nontoxic endophyte; or 3) no endophyte when stockpiled forages were sampled in winter.

Concentrations of NDF, ADF, and lignin exhibited cubic $(P \leq 0.027)$ relationships with sampling dates. Generally, concentrations of these fiber components increased steadily through the February 4 sampling date, followed by a small decline over the final sampling interval. Numerical maxima for NDF (66.4\%), ADF (32.4\%), and lignin $(7.69 \%)$ were observed on February 4, which represented increases of 18,17 , and $106 \%$ relative to initial concentrations in early December. Generally, hemicellulose also increased over time, but unlike all other fiber components, this response was explained by a quartic $(P=0.004)$ effect. Cellulose increased over time by $11 \%$ in a simple linear $(P=0.001)$ pattern, reaching a maximum of $27.8 \%$ on the final sampling date. Conversely, $\mathrm{CP}$ declined linearly $(P=$ 0.001 ) by $18 \%$ over sampling dates from a maximum of $15.6 \%$ on December 4 to $12.8 \%$ at the end of the trial.

Postgrazed Forages. No index of nutritive value was affected by either fescue type $(P \geq 0.512)$ or the interaction of fescue type $\times$ sampling date $(P \geq 0.102)$. A significant main effect for sampling date was ob- 
Table 3. Concentrations of CP, fiber components, and whole-plant ash for pregrazed (Pre) and postgrazed (Post) autumn-stockpiled tall fescue forages sampled on 5 dates between December 4, 2003, and February 26, 2004

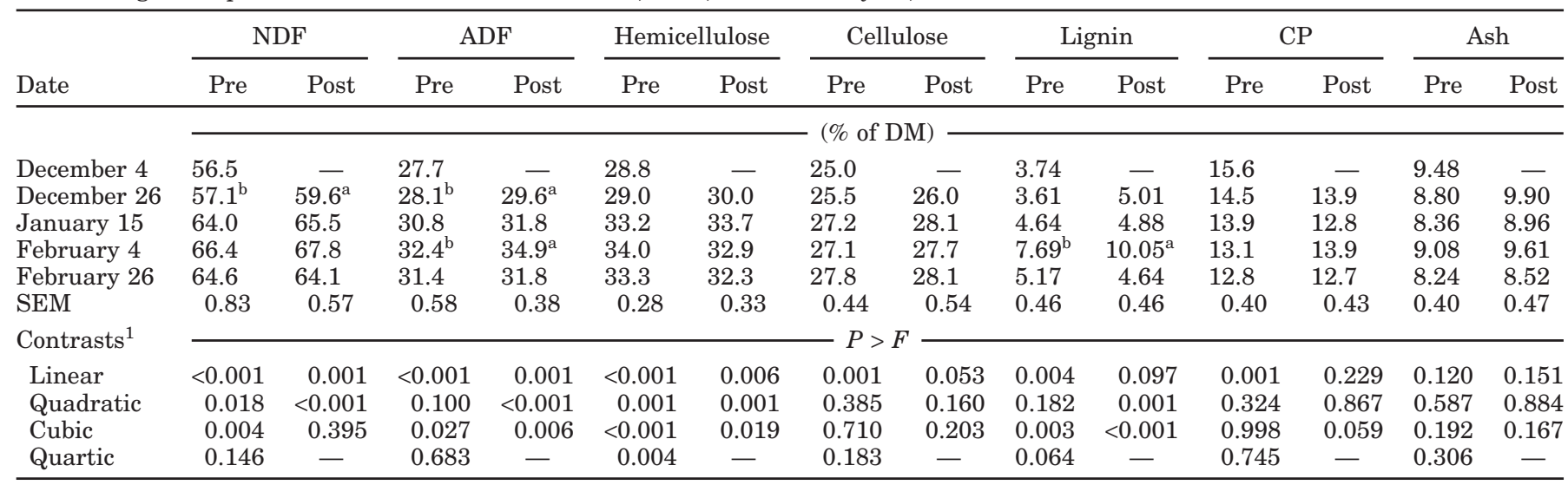

${ }^{\mathrm{a}, \mathrm{b}}$ Within each index of nutritive value and sampling date, means without common superscripts differ $(P \leq 0.05)$.

${ }^{1}$ Linear, quadratic, cubic, and quartic effects of sampling date.

served for $\mathrm{NDF}, \mathrm{ADF}$, hemicellulose, and lignin $(P \leq$ $0.001)$, but not for cellulose, $\mathrm{CP}$, and ash $(P \geq 0.091)$; therefore, only main effects of sampling date are reported and discussed (Table 3). Most fiber components changed in curvilinear patterns over time; however, these patterns were not consistent across nutritive indices. Concentrations of NDF exhibited a quadratic response $(P<0.001)$ over time, whereas $\operatorname{ADF}(P=0.006)$, hemicellulose $(P=0.019)$, and lignin $(P<0.001)$ changed cubically. As observed generally for pregrazed forages, declines in concentrations of each of these fiber components were observed between the last 2 sampling dates. Generally, there was little difference between pregrazed and postgrazed forages within sampling date; only 4 specific combinations of nutritive index and sampling date exhibited statistical $(P<0.05)$ differences based on grazing status (Table 3 ). Most prominent among these was the 2.36 percentage unit difference in lignin observed between pregrazed $(7.69 \%)$ and postgrazed (10.05\%) forages sampled on February 4.

\section{Disappearance Kinetics of DM}

Pregrazed Forage. The fescue type $\times$ sampling date interaction (Table 4$)$ affected both fraction $\mathrm{A}(P<0.001)$ and the effective ruminal disappearance of DM $(P=$ $0.007)$, and tendencies were observed for fractions B $(P=0.097)$ and $\mathrm{C}(P=0.071)$. Although these interactions suggest that different responses occurred for $\mathrm{E}+$ and HM4 over sampling dates, closer inspection of the data indicates that interactions or tendencies for interaction were created by minor fluctuations in the relative relationship between fescue types on specific sampling dates, rather than truly divergent responses over time. Furthermore, the magnitude of differences between fes- cue types on specific sampling dates was quite small, and likely of little biological importance. The only kinetic parameter exhibiting a main effect of fescue type was effective ruminal disappearance $(P=0.001)$, yet the mean difference between fescue types for this estimate was only 1.3 percentage units. Previously, Elizalde et al. (1999) found that parameters associated with DM disappearance of tall fescue forages did not differ on the basis of endophyte status. In contrast, Humphry et al. (2002) reported differences for some kinetic parameters that were related to endophyte status, but these differences may have been artifacts of alternative experimental methods in which forages were not evaluated kinetically on a common basal diet. For these reasons, and to simplify the presentation of results, only main-effect means are presented and discussed (Tables 5, 6, and 7).

Fractions A, B, and $\mathrm{C}$ each changed in a quartic ( $P$ $<0.001$ ) pattern over sampling dates. For fractions A and $\mathrm{B}$, these responses were dominated by sharp changes between December 26 and January 15. During this sampling interval, fraction A declined by 11.0 percentage units of DM, thereby indicating a loss of watersoluble components from the forage, whereas fraction B increased concurrently by 5.3 percentage units. Other changes, especially after the January 15 sampling date, were relatively static, and their biological significance was likely limited. Fraction C (Table 6), which is unavailable in the rumen, comprised the smallest proportion of total DM (13.6\%) on the initial sampling date, but increased to a maximum of $20.1 \%$ on January 15 , and then declined slightly thereafter.

Neither lag time nor Kd was affected ( $P \geq 0.127$; Table 4 ) by any aspect of the treatment structure. The overall mean lag time was relatively short (3.82 h; Table 6), 
Table 4. Abbreviated ANOVA for ruminal in situ disappearance kinetics ${ }^{1}$ of DM for pregrazed and postgrazed autumn-stockpiled tall fescue forages (HM4 or E+) sampled on 5 dates between December 4, 2003, and February 26, 2004

\begin{tabular}{|c|c|c|c|c|c|c|}
\hline \multirow[b]{2}{*}{ Source of variation } & \multicolumn{3}{|c|}{ Fraction } & \multirow[b]{2}{*}{ Lag time } & \multirow[b]{2}{*}{$\mathrm{Kd}$} & \multirow{2}{*}{$\begin{array}{c}\text { Effective } \\
\text { disappearance }\end{array}$} \\
\hline & A & B & $\mathrm{C}$ & & & \\
\hline & & & & $P>F$ & & \\
\hline \multicolumn{7}{|l|}{ Pregrazed forage } \\
\hline Fescue type $(\mathrm{F})$ & 0.269 & 0.408 & 0.122 & 0.477 & 0.127 & 0.001 \\
\hline Sampling date (D) & $<0.001$ & $<0.001$ & $<0.001$ & 0.228 & 0.314 & $<0.001$ \\
\hline $\mathrm{F} \times \mathrm{D}$ & $<0.001$ & 0.097 & 0.071 & 0.890 & 0.403 & 0.007 \\
\hline \multicolumn{7}{|l|}{ Postgrazed forage } \\
\hline Fescue type $(\mathrm{F})$ & $<0.001$ & 0.007 & 0.986 & 0.340 & 0.770 & 0.986 \\
\hline Sampling date (D) & $<0.001$ & $<0.001$ & $<0.001$ & 0.370 & 0.415 & $<0.001$ \\
\hline $\mathrm{F} \times \mathrm{D}$ & 0.007 & $<0.001$ & $<0.001$ & 0.071 & 0.240 & $<0.001$ \\
\hline
\end{tabular}

${ }^{1} \mathrm{~A}=$ immediately soluble fraction, $\mathrm{B}=$ fraction degradable at a measurable rate, $\mathrm{C}=$ undegradable fraction, and $\mathrm{Kd}=$ fractional degradation rate.

${ }^{2}$ Calculated as $\mathrm{A}+(\mathrm{B} \times[\mathrm{Kd} / \mathrm{Kd}+$ passage rate $])$, where $\mathrm{Kd}=$ ruminal degradation rate and passage rate $=$ $0.026 \pm 0.0036 \mathrm{~h}^{-1}$.

which compares closely to a previous estimate $(3.53 \mathrm{~h})$ for tall fescue hays (Turner et al., 2004). The overall $\mathrm{Kd}$ for pregrazed forages was $0.050 \mathrm{~h}^{-1}$ (Table 7), which was slower than reported by Elizalde et al. (1999) for fresh tall fescue forages during spring $\left(0.062 \mathrm{~h}^{-1}\right)$, but more rapid than various tall fescue hays (overall range $=0.031$ to $0.042 \mathrm{~h}^{-1}$; Humphry et al., 2002; Turner et al., 2004).

Estimates of effective ruminal disappearance (Table 7) ranged from 61.2 to $69.5 \%$, and changed in a quartic pattern over sampling dates; on a practical basis, the mean estimate for December sampling dates was $69.0 \%$ followed by a decline to $61.8 \%$ on January 15 , and relatively static responses thereafter. These estimates compare favorably with those of 5 perennial cool-season grasses harvested at the second node stage of growth in Wisconsin (overall range $=62.0$ to $75.8 \%$; Hoffman et al., 1993), and with estimates for tall fescue forages harvested at tillering and during stem elongation (overall range $=60.3$ to $70.1 \%$; Elizalde et al., 1999). The

Table 5. Fractions A and B for ruminal in situ disappearance ${ }^{1}$ of DM from pregrazed and postgrazed autumn-stockpiled tall fescue forages (HM4 or E+) sampled on 5 dates between December 4, 2003, and February 26, 2004

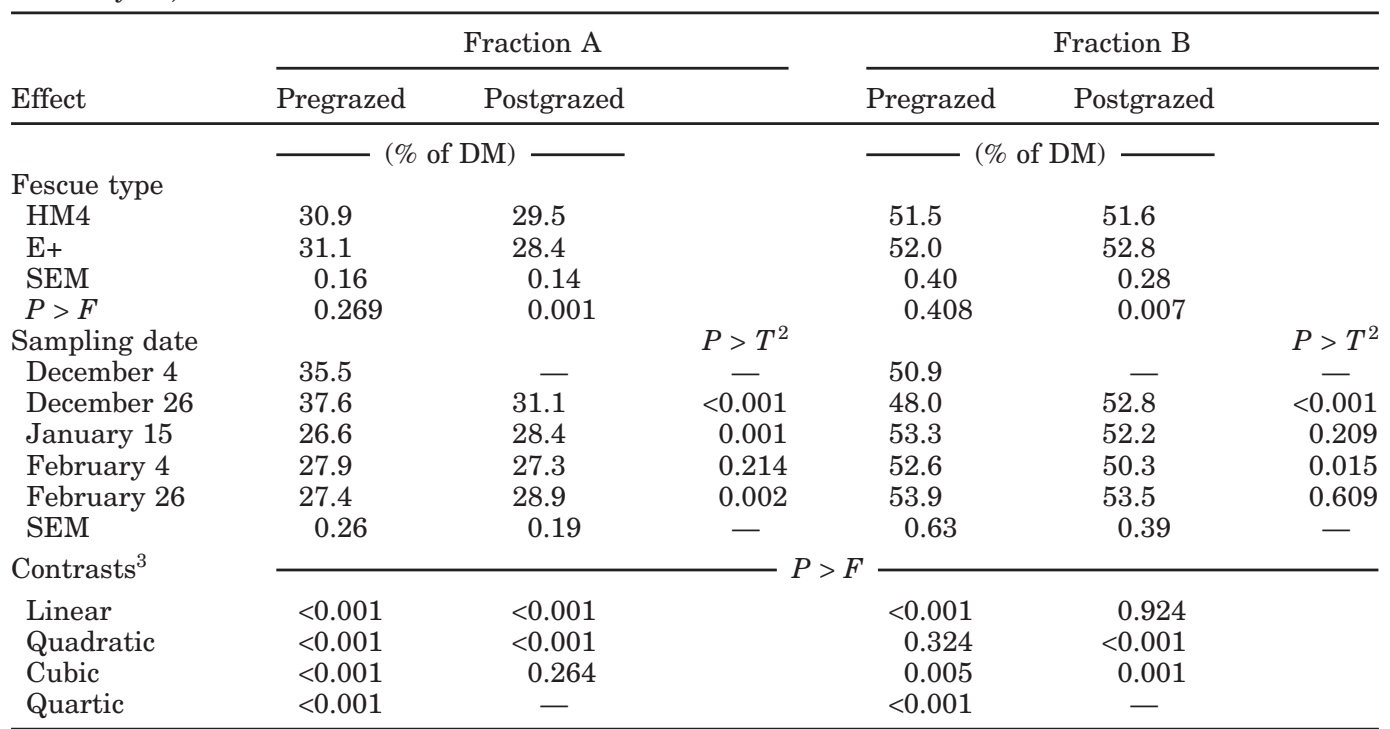

\footnotetext{
${ }^{1} \mathrm{~A}=$ immediately soluble fraction, and $\mathrm{B}=$ fraction degradable at a measurable rate.

${ }^{2}$ Within each sampling date, the probability that the difference between the means for pregrazed and postgrazed forages is equal to zero.

${ }^{3}$ Linear, quadratic, cubic, and quartic effects of sampling date.
} 
Table 6. Fraction $\mathrm{C}$ and lag time for ruminal in situ disappearance of DM from pregrazed and postgrazed autumn-stockpiled tall fescue forages (HM4 or E+) sampled on 5 dates between December 4, 2003, and February 26, 2004

\begin{tabular}{|c|c|c|c|c|c|c|}
\hline \multirow[b]{2}{*}{ Effect } & \multicolumn{3}{|c|}{ Fraction C } & \multicolumn{3}{|c|}{ Lag time } \\
\hline & Pregrazed & Postgrazed & & Pregrazed & Postgrazed & \\
\hline & $\longrightarrow(\%$ & M) & & $\longrightarrow$ & $\longrightarrow$ & \\
\hline \multicolumn{7}{|l|}{ Fescue type } \\
\hline HM4 & 17.6 & 18.9 & & 3.69 & 3.81 & \\
\hline $\mathrm{E}+$ & 16.9 & 18.9 & & 3.95 & 4.14 & \\
\hline SEM & 0.32 & 0.19 & & 0.256 & 0.240 & \\
\hline$P>F$ & 0.122 & 0.986 & & 0.477 & 0.340 & \\
\hline Sampling date & & & $P>T^{2}$ & & & $P>T^{2}$ \\
\hline December 4 & 13.6 & - & - & 2.97 & - & - \\
\hline December 26 & 14.4 & 16.1 & 0.024 & 4.15 & 3.61 & 0.310 \\
\hline January 15 & 20.1 & 19.5 & 0.348 & 3.97 & 4.14 & 0.740 \\
\hline February 4 & 19.5 & 22.4 & $<0.001$ & 3.87 & 4.39 & 0.324 \\
\hline February 26 & 18.7 & 17.6 & 0.130 & 4.14 & 3.76 & 0.475 \\
\hline SEM & 0.51 & 0.28 & - & 0.404 & 0.339 & - \\
\hline \multicolumn{7}{|l|}{ Contrasts $^{3}$} \\
\hline Linear & $<0.001$ & $<0.001$ & & 0.116 & 0.651 & \\
\hline Quadratic & $<0.001$ & $<0.001$ & & 0.257 & 0.099 & \\
\hline Cubic & 0.003 & $<0.001$ & & 0.179 & 0.702 & \\
\hline Quartic & $<0.001$ & - & & 0.735 & - & \\
\hline
\end{tabular}

${ }^{1} \mathrm{C}=$ undegradable fraction.

${ }^{2}$ Within each sampling date, the probability that the difference between the means for pregrazed and postgrazed forages is equal to zero.

${ }^{3}$ Linear, quadratic, cubic, and quartic effects of sampling date.

pregrazed stockpiled tall fescue forages evaluated in the present trial exhibited estimates of effective ruminal disappearance that were considerably greater than en- dophyte-infected tall fescue hays harvested in northern Arkansas during late May (overall range $=40.0$ to 45.8\%; Turner et al., 2004).

Table 7. Ruminal disappearance rate (Kd) and effective disappearance of DM for pregrazed and postgrazed autumn-stockpiled tall fescue forages (HM4 or E+) sampled on 5 dates between December 4, 2003, and February 26, 2004

\begin{tabular}{|c|c|c|c|c|c|c|}
\hline \multirow[b]{2}{*}{ Effect } & \multicolumn{3}{|c|}{$\mathrm{Kd}$} & \multicolumn{3}{|c|}{ Effective disappearance $^{1}$} \\
\hline & Pregrazed & Postgrazed & & Pregrazed & Postgrazed & \\
\hline & $\longrightarrow$ & 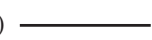 & & $-(\%$ & M) & \\
\hline \multicolumn{7}{|l|}{ Fescue type } \\
\hline HM4 & 0.048 & 0.050 & & 64.1 & 63.4 & \\
\hline $\mathrm{E}+$ & 0.051 & 0.049 & & 65.4 & 62.8 & \\
\hline SEM & 0.0016 & 0.0014 & & 0.26 & 0.26 & \\
\hline$P>T$ & 0.127 & 0.770 & & 0.001 & 0.184 & \\
\hline Sampling date & & & $P>T^{2}$ & & & $P>T^{2}$ \\
\hline December 4 & 0.048 & - & - & 68.4 & - & - \\
\hline December 26 & 0.054 & 0.047 & 0.033 & 69.5 & 64.9 & $<0.001$ \\
\hline January 15 & 0.051 & 0.051 & 0.894 & 61.8 & 63.0 & 0.098 \\
\hline February 4 & 0.047 & 0.051 & 0.115 & 61.2 & 60.7 & 0.466 \\
\hline February 26 & 0.049 & 0.049 & 0.841 & 62.7 & 63.8 & 0.102 \\
\hline SEM & 0.0026 & 0.0020 & - & 0.41 & 0.37 & - \\
\hline \multicolumn{7}{|l|}{ Contrasts $^{3}$} \\
\hline Linear & 0.597 & 0.586 & & $<0.001$ & 0.002 & \\
\hline Quadratic & 0.357 & 0.115 & & $<0.001$ & $<0.001$ & \\
\hline Cubic & 0.061 & 0.999 & & $<0.001$ & 0.002 & \\
\hline Quartic & 0.867 & - & & $<0.001$ & - & \\
\hline
\end{tabular}

${ }^{1}$ Calculated as $\mathrm{A}+(\mathrm{B} \times[\mathrm{Kd} / \mathrm{Kd}+$ passage rate $])$, where $\mathrm{Kd}=$ ruminal degradation rate and passage rate $=$ $0.026 \pm 0.0036 \mathrm{~h}^{-1}$.

${ }^{2}$ Within each sampling date, the probability that the difference between the means for pregrazed and postgrazed forages is equal to zero.

${ }^{3}$ Linear, quadratic, cubic, and quartic effects of sampling date. 
Table 8. Abbreviated ANOVA for ruminal in situ disappearance kinetics of NDF for pregrazed and postgrazed autumn-stockpiled tall fescue forages (HM4 or E+) sampled on 5 dates between December 4, 2003, and February $26,2004^{1}$

\begin{tabular}{|c|c|c|c|c|c|c|}
\hline \multirow[b]{2}{*}{ Source of variation } & \multicolumn{3}{|c|}{ Fraction } & \multirow[b]{2}{*}{ Lag time } & \multirow[b]{2}{*}{$\mathrm{Kd}$} & \multirow{2}{*}{$\begin{array}{c}\text { Effective } \\
\text { disappearance }\end{array}$} \\
\hline & A & B & $\mathrm{C}$ & & & \\
\hline & & & & $P>F$ & & \\
\hline \multicolumn{7}{|l|}{ Pregrazed forage } \\
\hline Fescue type $(\mathrm{F})$ & $<0.001$ & 0.021 & 0.514 & 0.272 & 0.079 & 0.115 \\
\hline Sampling date (D) & $<0.001$ & $<0.001$ & $<0.001$ & 0.056 & 0.344 & $<0.001$ \\
\hline $\mathrm{F} \times \mathrm{D}$ & $<0.001$ & 0.001 & 0.078 & 0.674 & 0.354 & 0.355 \\
\hline \multicolumn{7}{|l|}{ Postgrazed forage } \\
\hline Fescue type $(\mathrm{F})$ & $<0.001$ & 0.075 & 0.102 & 0.266 & 0.944 & 0.025 \\
\hline Sampling date (D) & $<0.001$ & $<0.001$ & $<0.001$ & 0.711 & 0.571 & $<0.001$ \\
\hline $\mathrm{F} \times \mathrm{D}$ & 0.058 & 0.002 & $<0.001$ & 0.206 & 0.296 & $<0.001$ \\
\hline
\end{tabular}

${ }^{1} \mathrm{~A}=$ immediately soluble fraction, $\mathrm{B}=$ fraction degradable at a measurable rate, $\mathrm{C}=$ undegradable fraction, and $\mathrm{Kd}=$ fractional degradation rate.

${ }^{2}$ Calculated as $\mathrm{A}+(\mathrm{B} \times[\mathrm{Kd} / \mathrm{Kd}+$ passage rate $])$, where $\mathrm{Kd}=$ ruminal degradation rate and passage rate $=$ $0.026 \pm 0.0036 \mathrm{~h}^{-1}$.

Postgrazed Forage. With the exceptions of lag time $(P \geq 0.099$; Table 6$)$ and $\mathrm{Kd}(P \geq 0.115$; Table 7), all kinetic parameters varied over sampling dates in curvilinear patterns. Fraction A declined in a quadratic $(P$ $<0.001$; Table 5) pattern, whereas fractions B and C, as well as effective ruminal disappearance, changed in a cubic $(P \leq 0.002$; Tables 5,6 , and 7$)$ relationship with time. Generally, only minor practical differences were observed for individual kinetic parameters when postgrazed forages were compared with pregrazed forages within specific sampling dates.

\section{Disappearance Kinetics of NDF}

Pregrazed Forage. For ruminal disappearance of $\mathrm{NDF}$, no fescue type $\times$ sampling date interactions $(P \geq$ 0.078 ) were observed for fraction $\mathrm{C}$, lag time, $\mathrm{Kd}$, or effective ruminal disappearance (Table 8). Although these interactions were observed for fractions A $(P<$ $0.001)$ and $\mathrm{B}(P=0.001)$, differences between fescue types appeared to vary randomly, rather than exhibiting any discernible pattern across sampling dates. Furthermore, the overall respective means for fractions $\mathrm{A}$ and $\mathrm{B}$ varied between fescue types by only 1.4 and 1.7 percentage units (Table 9), respectively. Although these differences were statistically significant $(P \leq$ 0.021 ), their relatively small range suggests limited biological importance. For these reasons, and to simplify the presentation of results, only main effect means are presented (Tables 9, 10, and 11).

Fraction A exhibited a complex, quartic $(P<0.001)$ relationship with sampling dates, and ranged from a minimum of $10.6 \%$ on January 15 to a maximum of $17.3 \%$ on February 4 (Table 9). Theoretically, forage components that are insoluble in neutral detergent are also assumed to be insoluble in water (Van Soest, 1982).
Therefore, by definition, none of the total NDF pool should be partitioned into fraction A because solubility in water has an overwhelming influence on the estimate of NDF recovery at time $0 \mathrm{~h}$, and (subsequently) on the $\gamma$-intercept of the nonlinear regression of NDF retention on incubation time from which fraction $\mathrm{A}$ is calculated. However, many studies (Hoffman et al., 1993; Coblentz et al., 1998; Galdámez-Cabrera et al., 2003) using in situ methodology have reported small percentages of the total NDF pool partitioned within fraction A. Generally, this fraction has been limited to approximately $10 \%$ of the total NDF pool or less, and is most likely explained by minute forage particles escaping the Dacron bags during rigorous machine washing (Coblentz et al., 1998; Galdámez-Cabrera et al., 2003). However, variable, but sometimes larger percentages, ranging from 2.4 to $29.4 \%$ of the total NDF pool, have been reported for immature perennial cool-season grasses grown in Wisconsin (Hoffman et al., 1993).

Fraction B declined in a quartic $(P=0.019)$ relationship with sampling dates; this fraction exhibited a maximum $(69.0 \%)$ on the initial sampling date, and remained relatively high thereafter, ranging from 59.9 to 65.3\% (Table 9). Conversely, fraction C comprised a relatively small percentage of the total NDF pool, ranging from 18.4 to $25.2 \%$ over sampling dates (Table 10). Although fraction $\mathrm{C}$ changed in a quartic $(P<0.001)$ pattern, the overall range was narrow, thereby indicating that potential ruminal availability was relatively stable over time.

Lag time changed in a quadratic $(P=0.032)$ relationship with sampling dates (Table 10) that was characterized by a minimum $(3.63 \mathrm{~h})$ on the initial sampling date, and a maximum (5.12 h) on January 15; estimates on all other dates varied little from the overall mean $(4.54 \mathrm{~h})$. Ruminal $\mathrm{Kd}$ did not vary $(P \geq 0.137)$ over 
Table 9. Fractions A and B for ruminal in situ disappearance of NDF from pregrazed and postgrazed autumn-stockpiled tall fescue forages (HM4 or E+) sampled on 5 dates between December 4, 2003, and February $26,2004^{1}$

\begin{tabular}{|c|c|c|c|c|c|c|}
\hline \multirow[b]{2}{*}{ Effect } & \multicolumn{3}{|c|}{ Fraction A } & \multicolumn{3}{|c|}{ Fraction B } \\
\hline & Pregrazed & Postgrazed & & Pregrazed & Postgrazed & \\
\hline & $\longrightarrow$ & DF) & & $\longrightarrow(\%$ & DF) & \\
\hline \multicolumn{7}{|l|}{ Fescue type } \\
\hline HM4 & 14.9 & 14.2 & & 63.4 & 62.7 & \\
\hline $\mathrm{E}+$ & 13.5 & 16.1 & & 65.1 & 61.5 & \\
\hline SEM & 0.21 & 0.32 & & 0.51 & 0.46 & \\
\hline$P>F$ & $<0.001$ & $<0.001$ & & 0.021 & 0.075 & \\
\hline Sampling date & & & $P>T^{2}$ & & & $P>T^{2}$ \\
\hline December 4 & 12.6 & - & - & 69.0 & - & - \\
\hline December 26 & 15.5 & 11.0 & $<0.001$ & 65.3 & 67.8 & 0.043 \\
\hline January 15 & 10.6 & 12.6 & 0.061 & 64.3 & 63.6 & 0.558 \\
\hline February 4 & 17.3 & 18.6 & 0.246 & 59.9 & 56.0 & 0.002 \\
\hline February 26 & 15.2 & 18.4 & 0.006 & 62.6 & 60.9 & 0.143 \\
\hline SEM & 0.33 & 0.46 & - & 0.81 & 0.64 & - \\
\hline \multicolumn{7}{|l|}{ Contrasts $^{3}$} \\
\hline Linear & $<0.001$ & $<0.001$ & & $<0.001$ & $<0.001$ & \\
\hline Quadratic & 0.169 & 0.056 & & 0.003 & $<0.001$ & \\
\hline Cubic & 0.314 & $<0.001$ & & 0.083 & $<0.001$ & \\
\hline Quartic & $<0.001$ & - & & 0.019 & - & \\
\hline
\end{tabular}

${ }^{1} \mathrm{~A}=$ immediately soluble fraction, and $\mathrm{B}=$ fraction degradable at a measurable rate.

${ }^{2}$ Within each sampling date, the probability that the difference between the means for pregrazed and postgrazed forages is equal to zero.

${ }^{3}$ Linear, quadratic, cubic, and quartic effects of sampling date.

sampling dates, averaging $0.048 \mathrm{~h}^{-1}$ over the entire trial; this rate agrees closely with other estimates for tall fescue forages (overall range $=0.036$ to $0.060 \mathrm{~h}^{-1}$ ) conducted with in situ methodology (Humphry et al., 2002; Turner et al., 2004). Effective ruminal disappearance of NDF exhibited a quartic $(P<0.001)$ relationship

Table 10. Fraction $\mathrm{C}$ and lag time for ruminal in situ disappearance of NDF from pregrazed and postgrazed autumn-stockpiled tall fescue forages (HM4 or E+) sampled on 5 dates between December 4, 2003, and February 26, 2004

\begin{tabular}{|c|c|c|c|c|c|c|}
\hline \multirow[b]{2}{*}{ Effect } & \multicolumn{3}{|c|}{ Fraction $\mathrm{C}^{1}$} & \multicolumn{3}{|c|}{ Lag time } \\
\hline & Pregrazed & Postgrazed & & Pregrazed & Postgrazed & \\
\hline & $\longrightarrow$ & IDF) & & $\longrightarrow$ & 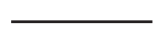 & \\
\hline \multicolumn{7}{|l|}{ Fescue type } \\
\hline HM4 & 21.7 & 23.1 & & 4.36 & 4.33 & \\
\hline $\mathrm{E}+$ & 21.4 & 22.4 & & 4.71 & 4.81 & \\
\hline SEM & 0.40 & 0.28 & & 0.223 & 0.300 & \\
\hline$P>F$ & 0.514 & 0.102 & & 0.272 & 0.266 & \\
\hline Sampling date & & & \multicolumn{3}{|l|}{$P>T^{2}$} & $P>T^{2}$ \\
\hline December 4 & 18.4 & - & - & 3.63 & - & - \\
\hline December 26 & 19.2 & 21.2 & 0.037 & 4.44 & 4.41 & 0.957 \\
\hline January 15 & 25.2 & 23.8 & 0.136 & 5.12 & 4.36 & 0.172 \\
\hline February 4 & 22.8 & 25.4 & 0.008 & 4.84 & 4.99 & 0.793 \\
\hline February 26 & 22.1 & 20.7 & 0.132 & 4.65 & 4.52 & 0.819 \\
\hline SEM & 0.64 & 0.40 & - & 0.353 & 0.42 & - \\
\hline \multicolumn{7}{|l|}{ Contrasts $^{3}$} \\
\hline Linear & $<0.001$ & 0.918 & & 0.036 & 0.611 & \\
\hline Quadratic & $<0.001$ & $<0.001$ & & 0.032 & 0.629 & \\
\hline Cubic & 0.092 & 0.005 & & 0.859 & 0.355 & \\
\hline Quartic & $<0.001$ & - & & 0.531 & - & \\
\hline
\end{tabular}

${ }^{1} \mathrm{C}=$ undegradable fraction.

${ }^{2}$ Within each sampling date, the probability that the difference between the means for pregrazed and postgrazed forages is equal to zero.

${ }^{3}$ Linear, quadratic, cubic, and quartic effects of sampling date. 
Table 11. Ruminal disappearance rate (Kd) and effective disappearance of NDF for pregrazed and postgrazed autumn-stockpiled tall fescue forages (HM4 or E+) sampled on 5 dates between December 4, 2003, and February 26, 2004

\begin{tabular}{|c|c|c|c|c|c|c|}
\hline \multirow[b]{2}{*}{ Effect } & \multicolumn{3}{|c|}{$\mathrm{Kd}$} & \multicolumn{3}{|c|}{ Effective disappearance $^{1}$} \\
\hline & Pregrazed & Postgrazed & & Pregrazed & Postgrazed & \\
\hline & $\longrightarrow$ & $\longrightarrow$ & & $\longrightarrow(\%$ & M) & \\
\hline \multicolumn{7}{|l|}{ Fescue type } \\
\hline HM4 & 0.046 & 0.048 & & 55.2 & 54.6 & \\
\hline $\mathrm{E}+$ & 0.050 & 0.048 & & 56.0 & 55.9 & \\
\hline SEM & 0.0014 & 0.0015 & & 0.33 & 0.37 & \\
\hline$P>T$ & 0.079 & 0.944 & & 0.115 & 0.025 & \\
\hline Sampling date & & & $P>T^{2}$ & & & $P>T^{2}$ \\
\hline December 4 & 0.045 & - & - & 56.4 & - & - \\
\hline December 26 & 0.050 & 0.046 & 0.245 & 57.8 & 53.9 & $<0.001$ \\
\hline January 15 & 0.051 & 0.049 & 0.368 & 52.9 & 54.1 & 0.193 \\
\hline February 4 & 0.046 & 0.050 & 0.197 & 55.2 & 55.4 & 0.838 \\
\hline February 26 & 0.047 & 0.047 & 0.920 & 55.6 & 57.6 & 0.022 \\
\hline SEM & 0.0023 & 0.0021 & - & 0.52 & 0.53 & - \\
\hline \multicolumn{7}{|l|}{ Contrasts $^{3}$} \\
\hline Linear & 0.989 & 0.701 & & 0.020 & $<0.001$ & \\
\hline Quadratic & 0.137 & 0.192 & & 0.013 & 0.055 & \\
\hline Cubic & 0.240 & 0.748 & & 0.013 & 0.895 & \\
\hline Quartic & 0.348 & - & & $<0.001$ & - & \\
\hline
\end{tabular}

${ }^{1}$ Calculated as $\mathrm{A}+(\mathrm{B} \times[\mathrm{Kd} / \mathrm{Kd}+$ passage rate $])$, where $\mathrm{Kd}=$ ruminal degradation rate and passage rate $=$ $0.026 \pm 0.0036 \mathrm{~h}^{-1}$.

${ }^{2}$ Within each sampling date, the probability that the difference between the means for pregrazed and postgrazed forages is equal to zero.

${ }^{3}$ Linear, quadratic, cubic, and quartic effects of sampling date.

with sampling dates; however, the overall range of estimates remained relatively narrow (52.9 to 57.8\%) throughout the trial, thereby indicating excellent nutritional stability over the entire winter. Relatively minor date-to-date fluctuations observed for effective disappearance and other kinetic parameters may be related to the complex and dynamic relationship between temperature and nutritive value described by Kallenbach et al. (2003). Intermittent periods of warmer temperatures are common throughout the winter months in northern Arkansas, and they likely initiate brief periods of new forage growth, but also may accelerate deterioration of older tissues. Although these processes may have relatively little effect on available forage mass, they theoretically have competing relationships on both nutritive value and kinetic characteristics.

Postgrazed Forage. Fractions A, B, and C for postgrazed forages all changed in cubic $(P \leq 0.005)$ patterns over sampling dates (Tables 9 and 10); however, these effects generally increased the magnitude of fraction A, decreased fraction $\mathrm{B}$, and had little net effect on fraction C. In contrast, effective ruminal disappearance of NDF increased in a simple linear $(P<0.001)$ relationship with sampling dates (Table 11). The overall range of disappearance estimates was relatively small (53.9 to $57.6 \%$ ), again indicating excellent stability over time with respect to fiber disappearance. Neither lag time nor Kd exhibited any polynomial relationship with time
$(P \geq 0.192)$. As observed for disappearance kinetics of $\mathrm{DM}$, there were cases where kinetic estimates varied between pregrazed and postgrazed forages within sampling date. However, these differences created by defoliation and trampling by heifers did not reveal any discernible patterns across dates, and were generally limited in magnitude.

\section{CONCLUSIONS}

Properly managed, autumn-stockpiled tall fescue forages exhibited good nutritive value and associated characteristics of ruminal disappearance for DM and NDF that suggest it can be incorporated easily into diets of developing dairy heifers. Using the summative equation for estimating total digestible nutrients (NRC, 2001), energy densities for pregrazed, autumn-stockpiled tall fescue forages ranged from about 68 to $62 \%$ during the utilization period between early December and late February. Based strictly on these estimates, it should be possible to meet the energy requirements for developing dairy heifers targeted at a $0.8-\mathrm{kg}$ rate of daily gain with little or no energy supplementation (NRC, 2001); however, Poore et al. (2000) also concluded that animal performance may be poorer than predicted from nutrient composition. This apparent inconsistency needs further evaluation. 
Nutritive traits exhibited by stockpiled forages are likely to be superior to those of hays made from fully headed tall fescue that is often used as supplemental forage during winter months. Based on the results of this trial, the endophyte status of stockpiled tall fescue forages had little practical effect on forage nutritive value or kinetics of ruminal disappearance. This suggests that any differences in performance by grazing livestock are more likely related to toxin loads produced by the endophytic association than by inherent differences in the nutritional composition of the forages. Furthermore, the nutritional characteristics of stockpiled tall fescue forages exhibited little practical deterioration throughout the winter months. It remains unclear whether this resistance to deterioration occurs as a result of physical or biochemical limitations to deterioration of older leaves, generation of new growth at relatively low temperatures, or both. Overall, autumnstockpiled tall fescue forage would appear to be a legitimate and lower cost alternative to harvested forages that is suitable for developing dairy heifers in the southern Ozark Highlands.

\section{REFERENCES}

AOAC. 1998. Official Methods of Analysis. 16th ed. Association of Official Analytical Chemists, Gaithersburg, MD.

Bouton, J. H., R. N. Gates, D. P. Belesky, and M. Owsley. 1993. Yield and persistence of tall fescue in the southeastern coastal plain after removal of its endophyte. Agron. J. 85:52-55.

Bouton, J. H., G. C. M. Latch, N. S. Hill, C. S. Hoveland, M. A. McCann, R. H. Watson, J. A. Parish, L. L. Hawkins, and F. N. Thompson. 2002. Reinfection of tall fescue cultivars with nonergot alkaloid-producing endophytes. Agron. J. 94:567-574.

Burns, J. C., D. S. Fisher, and G. E. Rottinghaus. 2006. Grazing influences on mass, nutritive value, and persistence of stockpiled Jessup tall fescue without and with novel and wild-type fungal endophytes. Crop Sci. 46:1898-1912.

Chapman, S. L. 2001. Soil Test Recommendations Guide \# AGR 9. Coop. Ext. Serv. Agric. Exp. Sta., Univ. of Arkansas. Little Rock.

Coblentz, W. K., K. P. Coffey, T. F. Smith, D. S. Hubbell, III, D. A. Scarbrough, J. B. Humphry, B. C. McGinley, J. E. Turner, J. A. Jennings, C. P. West, M. P. Popp, D. H. Hellwig, D. L. Kreider, and C. F. Rosenkrans, Jr. 2006. Using orchardgrass and endophyte-free fescue versus endophyte-infected fescue overseeded on bermudagrass for cow herds: Four-year summary of cow-calf performance. Crop Sci. 46:1929-1938.

Coblentz, W. K., J. O. Fritz, R. C. Cochran, W. L. Rooney, and K. K. Bolsen. 1997. Protein degradation responses to spontaneous heating in alfalfa hay by in situ and ficin methods. J. Dairy Sci. 80:700-713

Coblentz, W. K., J. O. Fritz, W. H. Fick, R. C. Cochran, and J. E. Shirley. 1998. In situ dry matter, nitrogen, and fiber degradation of alfalfa, red clover, and eastern gamagrass at four maturities. J. Dairy Sci. 81:150-161.

Elizalde, J. C., N. R. Merchen, and D. B. Faulkner. 1999. In situ dry matter and crude protein degradation of fresh forages during the spring growth. J. Dairy Sci. 82:1978-1990.

Fribourg, H. A., A. B. Chestnut, R. W. Thompson, J. B. McLaren, R. J. Carlisle, K. D. Gwinn, M. C. Dixon, and M. C. Smith. 1991. Steer performance in fescue-clover pastures with different levels of endophyte infestation. Agron. J. 83:777-781.
Fritz, J. O., and M. Collins. 1991. Yield, digestibility, and chemical composition of endophyte free and infected tall fescue. Agron. J. 83:537-541.

Forcherio, J. C., G. E. Catlett, J. A. Paterson, M. S. Kerley, and M. R. Ellersieck. 1995. Supplemental protein and energy for beef cows consuming endophyte-infected tall fescue. J. Anim. Sci. 73:3427-3436.

Galdámez-Cabrera, N. W., K. P. Coffey, W. K. Coblentz, J. E. Turner, D. A. Scarbrough, Z. B. Johnson, J. L. Gunsaulis, M. B. Daniels, and D. H. Hellwig. 2003. In situ degradation of dry matter and fiber from bermudagrass fertilized with different nitrogen rates and harvested on two dates. Anim. Feed Sci. Technol. 105:185198.

Glenn, A. E., C. W. Bacon, R. Price, and R. T. Hanlin. 1996. Molecular physiology of Acremonium and its taxonomic implications. Mycology 88:369-383.

Goetsch, A. L., A. L. Jones, K. W. Beers, S. R. Stokes, and E. L. Piper. 1987. Effects of offering different amounts and types of supplemental feeds to growing dairy steers fed endophyte-infected fescue hay ad libitum on intake, digestion, passage rate and serum prolactin concentration. J. Anim. Sci. 64:1769-1778.

Hannah, S. M., J. A. Paterson, J. E. Williams, M. S. Kerley, and J. L. Miner. 1990. Effects of increasing dietary levels of endophyteinfected tall fescue seed on diet digestibility and ruminal kinetics in sheep. J. Anim. Sci. 68:1693-1701.

Hoffman, P. C., S. J. Sievert, R. D. Shaver, D. A. Welch, and D. K. Combs. 1993. In situ dry matter, protein, and fiber degradation of perennial forages. J. Dairy Sci. 76:2632-2643.

Holloway, J. W., and W. T. Butts, Jr. 1984. Influence of cow frame size and fatness on seasonal patterns of forage intake, performance and efficiency of Angus cow-calf pairs grazing fescue-legume or fescue pastures. J. Anim. Sci. 59:1411-1422.

Hoveland, C. S. 1993. Importance and economic significance of the Acremonium endophytes to performance of animals and grass plant. Agric. Ecosyst. Environ. 44:3-12.

Humphry, J. B., K. P. Coffey, J. L. Moyer, F. K. Brazle, and L. W. Lomas. 2002. Intake, digestion, and digestive characteristics of Neotyphodium coenophialum-infected and uninfected fescue by heifers offered hay diets supplemented with Aspergillus oryzae fermentation extract or laidlomycin propionate. J. Anim. Sci. 80:225-234.

Kallenbach, R. L., G. J. Bishop-Hurley, M. D. Massie, G. E. Rottinghaus, and C. P. West. 2003. Herbage mass, nutritive value, and ergovaline concentration of stockpiled tall fescue. Crop Sci. 43:1001-1005.

Malinowski, D. P., and D. P. Belesky. 2000. Adaptation of endophyteinfected cool-season grasses to environmental stresses: Mechanisms of drought and mineral stress tolerance. Crop Sci. 40:923-940.

McMurphy, W. E., K. S. Lusby, S. C. Smith, S. H. Muntz, and C. A. Strasia. 1990. Steer performance on tall fescue pasture. J. Prod. Agric. 3:100-102.

Mertens, D. R., and J. R. Loften. 1980. The effect of starch on forage fiber digestion kinetics in vitro. J. Dairy Sci. 63:1437-1446.

Moubarak, A. S., E. L. Piper, Z. B. Johnson, and M. Flieger. 1996. HPLC method of detection of ergotamine, ergosine, and ergine after intravenous injection of a single dose. J. Agric. Food Chem. 44:146-148.

Nihsen, M. E., E. L. Piper, C. P. West, R. J. Crawford, Jr., T. M. Denard, Z. B. Johnson, C. A. Roberts, D. A. Spiers, and C. F. Rosenkrans, Jr. 2004. Growth rate and physiology of steers grazing tall fescue inoculated with novel endophytes. J. Anim. Sci. 82:878-883.

NOAA (National Oceanic and Atmospheric Administration). 2002. Monthly station normals of temperature, precipitation, and heating and cooling degree days 1971-2000. Climatography of the United States No. 81. 03 Arkansas. National Climatic Data Center, NESDIS, NOAA, Asheville, NC.

NRC. 2001. Nutrient Requirements of Dairy Cattle. 7th rev. ed. National Academy Press, Washington, DC.

Ørskov, E. R., and I. McDonald. 1979. The estimation of protein degradability in the rumen from incubation measurements 
weighted according to rate of passage. J. Agric. Sci. (Camb.) 92:499-503.

Parish, J. A., M. A. McCann, R. H. Watson, N. N. Paiva, C. S. Hoveland, A. H. Parks, B. L. Upchurch, N. S. Hill, and J. H. Bouton. 2003. Use of non-ergot alkaloid producing endophytes for alleviating tall fescue toxicosis in stocker cattle. J. Anim. Sci. $81: 2856-2868$.

Peters, C. W., K. N. Grigsby, C. G. Aldrich, J. A. Paterson, R. J. Lipsey, M. S. Kerley, and G. B. Garner. 1992. Performance, forage utilization, and ergovaline consumption by beef cows grazing endophyte fungus-infected tall fescue, endophyte fungus-free tall fescue, or orchardgrass pasture. J. Anim. Sci. 70:1550-1561.

Poore, M. H., G. A. Benson, M. E. Scott, and J. T. Green. 2000. Production and use of stockpiled fescue to reduce beef cattle production costs. Proc. Am. Soc. Anim. Sci. http://www.asas.org/symposia/0622.pdf Accessed Dec. 11, 2006.

SAS Institute. 1990. SAS/STAT: User's guide. Version 6, 4th ed. SAS Institute, Inc., Cary, NC.

Sauer, T. J., P. A. Moore, Jr., K. P. Coffey, and E. M. Rutledge. 1998. Characterizing the surface properties of soils at varying landscape positions in the Ozark highlands. Soil Sci. 163:907-915.

Teutsch, C. D., J. H. Fike, G. E. Groover, and S. Aref. 2005. Nitrogen rate and source effects on the yield and nutritive value of tall fescue stockpiled for winter grazing. Online. Forage and Grazinglands. http://www.plantmanagementnetwork.org/sub/fg/ research/2005/winter/ Accessed Mar. 15, 2007.
Turner, J. E., W. K. Coblentz, K. P. Coffey, R. T. Rhein, B. C. McGinley, N. W. Galdámez-Cabrerra, C. F. Rosenkrans, Jr., Z. B. Johnson, D. W. Kellogg, and J. V. Skinner, Jr. 2004. Effects of natural rainfall and spontaneous heating on voluntary intake, digestibility, in situ disappearance kinetics, passage kinetics, and ruminal fermentation characteristics of tall fescue hay. Anim. Feed Sci. Technol. 116:15-33.

Van Soest, P. J. 1982. Nutritional Ecology of the Ruminant. Cornell University Press, Ithaca, NY.

Vanzant, E. S., R. C. Cochran, and E. C. Titgemeyer. 1998. Standardization of in situ techniques for ruminant feedstuff evaluation. J. Anim. Sci. 76:2717-2729.

Vanzant, E. S., R. C. Cochran, E. C. Titgemeyer, S. D. Stafford, K. C. Olsen, D. E. Johnson, and G. St. Jean. 1996. In vivo and in situ measurements of forage protein degradation in cattle. J. Anim. Sci. 74:2773-2784.

Waldo, D. R., L. W. Smith, and E. L. Cox. 1972. Model of cellulose disappearance from the rumen. J. Dairy Sci. 55:125-129.

Watson, R. H., M. A. McCann, J. A. Parish, C. S. Hoveland, F. N. Thompson, and J. H. Bouton. 2004. Productivity of cow-calf pairs grazing tall fescue pastures infected with either the wild-type endophyte or a nonergot alkaloid-producing endophyte strain, AR542. J. Anim. Sci. 82:3388-3393.

West, C. P., E. Izekor, K. E. Turner, and A. A. Elmi. 1993. Endophyte effects on growth and persistence of tall fescue along a water supply gradient. Agron. J. 85:264-270. 